\title{
Isolation, Molecular Characterisation and Genome Sequence of a Bacteriophage (Chp3) from Chlamydophila pecorum
}

\author{
SARAH A. GARNER, ${ }^{1, *}$ J. SYLVIA EVERSON, ${ }^{1}$ PAUL R. LAMBDEN,${ }^{1}$ BENTLEY A. FANE ${ }^{2}$ \\ \& IAN N. CLARKE ${ }^{1}$ \\ ${ }^{1}$ Molecular Microbiology and Infection, University Medical School, Southampton General Hospital, Southampton SO16 6 YD, UK \\ ${ }^{2}$ Department of Veterinary Science and Microbiology, The University of Arizona, Tucson, Arizona 85721-0090, USA
}

Received September 16 2003; Accepted November 3, 2003

\begin{abstract}
Chlamydiae are obligate intracellular pathogens that have a unique developmental cycle. Thirty nine viable isolates representing all nine currently recognised chlamydial species were screened by immunofluorescence with a cross-reacting chlamydiaphage monoclonal antibody. A novel chlamydiaphage (Chp3) was detected in C. pecorum, a chlamydial species not previously known to carry bacteriophages. Chp3 belongs to the Microviridae, members of this virus family are characterised by circular, single-stranded DNA genomes and small $T=1$ icosahedral capsids. Double-stranded replicative form Chp3 DNA was purified from elementary bodies and used as a template to determine the complete genome sequence. The genome of Chp3 is 4,554 base pairs and encodes eight open reading frames organised in the same genome structure as other chlamydiaphages. An unrooted phylogenetic tree was constructed based on the major coat proteins of 11 members of the Microviridae and Chp3. This showed that the Microviridae are clearly divided into two discrete sub-families; those that infect the Enterobacteriaceae e.g. ØX174 and the bacteriophages that infect obligate intracellular bacteria or mollicutes including SpV4 (Spiroplasma melliferum), ØМН2K (Bdellovibrio bacteriovorus) and the chlamydiaphages. Comparative analyses demonstrate that the chlamydiaphages can be further subdivided into two groupings, one represented by $\mathrm{Chp} 2 / \mathrm{Chp} 3$ and the other by ØCPG1/ØCPAR39.
\end{abstract}

Key words: bacteriophage, chlamydiaphage, Chp3, Chlamydophila pecorum, Microviridae, microvirus

\section{Introduction}

Chlamydiae are intracellular pathogens that have a unique developmental cycle. Eukaryotic cells are infected by the elementary body (EB) which, following uptake, grow and divide within a modified cytoplasmic eukaryotic host cell compartment called an inclusion. The inclusion expands to accommodate increasing numbers of the metabolically active, replicating form of the organism (the

\footnotetext{
*Author for all correspondence:

E-mail:sag1@soton.ac.uk
}

reticulate body or RB). RBs are not exposed to the extracellular environment and they differentiate into EBs within inclusions prior to cell lysis. The unique intracellular developmental cycle reduces the opportunity for chlamydiae to interact with bacteriophages of the free-living bacteria. The first chlamydial bacteriophage to be characterised (Chp1) was found by thin section transmission EM of avian C. psittaci RBs [1] where it formed characteristic paracrystalline arrays. Although Chp1 was later lost a second bacteriophage (ØCPG1) [2] was found infecting $C$. caviae and a third bacteriophage (Chp2) was isolated from C. abortus [3]. The genome sequencing project of $C$. pneumoniae strain AR39 revealed the presence of a dsDNA 
extrachromosomal element [4] which was subsequently shown to be the replicative form of bacteriophage ØCPAR39 [5]. These four bacteriophages share similar features, they are small icosahedral $T=1$ particles containing circular, single-stranded DNA genomes and molecular characterisation showed that they belong to the virus family Microviridae [3,4,6,7].

Biological analysis of the Microviridae suggests that they form two distinct sub-families: firstly, those that replicate in the free-living enterobacteria e.g. the prototypical coliphage ØX174 [8] and related bacteriophages; secondly those that infect obligate intracellular bacteria or mollicutes, including chlamydiaphages [1-4], a bacteriophage of spiroplasma (SpV4) [9] and a novel bacteriophage, ØМН2K [10] recently isolated from Bdellovibrio bacteriovorus. This second sub-family also has a similar overall genome organisation although the genomes of bacteriophages in this sub-family are smaller and do not encode homologues to the major spike and the external scaffold proteins [3] of the ØX174 subfamily.

The intracellular nature of the developmental cycle has greatly hampered the study of chlamydiae. Although, complete chromosomal sequences are available for several chlamydial species, which is a significant advance, [4,11-14]; the elucidation of gene-structure function relationships has been slow, due to the absence of genetic methods, such as gene transfer and mutant isolation [15]. Thus studies of chlamydial bacteriophages are of great interest as these agents offer a potential natural means of transferring DNA between cells.

The four chlamydiaphages that have been characterised were all discovered by chance [1-4]. The purpose of this work was to define the nature and extent of chlamydiaphage diversity by searching for new chlamydial microviruses using a systematic approach by screening a large collection of viable chlamydiae representing the six species of Chlamydophila and three species of Chlamydia. We describe the discovery, isolation and molecular characterisation of a new chlamydiaphage (Chp3). Chp3 infects a field isolate of C. pecorum, a chlamydial species not previously associated with bacteriophages forming a new group that differs from ØCPG1 and it's close relative ØCPAR39.

\section{Methods}

\section{Cells and Chlamydiae}

BGMK cells were grown in Dulbecco's modified Eagles medium (DMEM) supplemented with 10\% ( vol/vol) foetal calf serum. Cells were infected with chlamydiae by centrifugation at $1,000 \times g$ for $1 \mathrm{~h}$ in medium containing cycloheximide $(1 \mu \mathrm{g} / \mathrm{ml})$ and gentamicin $(25 \mu \mathrm{g} / \mathrm{ml})$. Thirty nine chlamydial isolates were screened for naturally occurring chlamydiaphage infections (Table 1). Preparations of chlamydiae were speciated and verified by PCR using primers U23F and 23SIGR followed by DNA sequence analysis and BLAST searching of the GenBank database as previously described [32]. Infected monolayers were detached with phosphate buffered saline (PBS) containing $0.125 \%$ trypsin $/ 0.02 \%$ EDTA and pelleted in DMEM containing $10 \% \mathrm{FCS}$ at $3,000 \times g$ for $10 \mathrm{~min}$. The infected cell pellet was suspended in $\mathrm{PBS}: \mathrm{H}_{2} \mathrm{O}$ (1:10) and homogenised in a Dounce homogeniser to break open cells and release the EBs. Cell debris was sedimented at $250 \times g$ for $5 \mathrm{~min}$ and the supernatant containing partially purified chlamydiae was mixed with an equal volume of phosphate buffer containing $0.4 \mathrm{M}$ sucrose, stored at $-80^{\circ} \mathrm{C}$ and used for chlamydiaphage challenge studies.

\section{Fluorescence Antibody Screening for Chlamydiaphages}

BGMK or Hep-2 cells were grown on $13 \mathrm{~mm}$ coverslips in 24-well trays. Cells were infected with chlamydiae (39 isolates - see Table 1). From 48 to $72 \mathrm{~h}$ post infection (dependent on host strain), the culture medium was removed, monolayers washed twice in PBS and fixed in ice cold methanol for $15 \mathrm{~min}$. Monoclonal antibody 55 was incubated with fixed cells for $40 \mathrm{~min}$ at $37^{\circ} \mathrm{C}$, washed three times in PBS. Bound antibody was detected with an anti-mouse fluorescein conjugated antibody (ISL, Paignton, UK) diluted in $0.0025 \%$ Evans Blue dye in PBS.

\section{Sequence Determination of Chp3}

The double stranded RF DNA of Chp3 was purified from an EB suspension of C. pecorum T52 
Table 1. Chlamydial strains used in this study

\begin{tabular}{|c|c|c|c|c|}
\hline Genus & Species & Strain & Host species & Source or reference \\
\hline Chlamydophila & $\begin{array}{l}\text { C. psittaci } \\
\text { C. felis } \\
\text { C. caviae } \\
\text { C. pecorum } \\
\text { C. pneumoniae }\end{array}$ & $\begin{array}{l}\text { A22 } \\
\text { S26/3 } \\
\text { S95/3 } \\
\text { B577 } \\
\text { IPA } \\
\text { T35 } \\
\text { BA1 } \\
\text { Colo } 4 \\
\text { B111 } \\
\text { BS } \\
\text { EAE } \\
\text { 6BC } \\
\text { Cal 10 } \\
\text { FP } \\
\text { GPIC } \\
\text { E58 } \\
\text { BE53 } \\
\text { Stra } \\
\text { MO-901 } \\
\text { LW508 } \\
\text { T52 } \\
\text { CWL029 } \\
\text { IOL 207 } \\
\text { TW183 } \\
\text { N16 }\end{array}$ & $\begin{array}{l}\text { Ovine } \\
\text { Ovine } \\
\text { Ovine } \\
\text { Ovine } \\
\text { Ovine } \\
\text { Ovine } \\
\text { Bovine } \\
\text { Bovine } \\
\text { Ovine } \\
\text { Ovine } \\
\text { Ovine } \\
\text { Avian } \\
\text { Avian } \\
\text { Feline } \\
\text { Cavia sp. } \\
\text { Bovine } \\
\text { Bovine } \\
\text { Ovine } \\
\text { Ovine } \\
\text { Bovine } \\
\text { Ovine } \\
\text { Human } \\
\text { Human } \\
\text { Human } \\
\text { Human }\end{array}$ & $\begin{array}{l}{[16]} \\
{[17]} \\
\text { G. Jones } \\
\text { VR-656 } \\
\text { VR-629 } \\
\text { [18] } \\
\text { [19] } \\
\text { P. Griffiths } \\
\text { P. Griffiths } \\
\text { [18] } \\
\text { [16] } \\
\text { VR-125 } \\
\text { [20] } \\
\text { [21] } \\
\text { VR-813 } \\
\text { VR-628 } \\
\text { P. Griffiths } \\
\text { [22] } \\
\text { [22] } \\
\text { [22] } \\
\text { P. Griffiths } \\
\text { VR-1310 } \\
\text { [23] } \\
\text { VR-2282 } \\
\text { [24] }\end{array}$ \\
\hline Chlamydia & $\begin{array}{l}\text { C. muridarum } \\
\text { C. suis }\end{array}$ & $\begin{array}{l}\text { L1/440/LN } \\
\text { L2/434/BU } \\
\text { IOL } 1883 \\
\text { IOL 238 } \\
\text { UW 36 } \\
\text { IU } 888 \\
\text { TW-5 } \\
\text { UW-1 } \\
\text { NL-D } \\
\text { NI 1 } \\
\text { Jali } 5 \\
\text { Jali } 20 \\
\text { Mo Pn } \\
\text { DC 6 }\end{array}$ & $\begin{array}{l}\text { Human } \\
\text { Human } \\
\text { Human } \\
\text { Human } \\
\text { Human } \\
\text { Human } \\
\text { Human } \\
\text { Human } \\
\text { Human } \\
\text { Human } \\
\text { Human } \\
\text { Human } \\
\text { Murine } \\
\text { Porcine }\end{array}$ & $\begin{array}{l}{[25]} \\
\text { VR-902B } \\
\text { J. Treharne } \\
\text { J. Treharne } \\
\text { VR-886 } \\
{[26]} \\
{[27]} \\
{[28]} \\
{[29]} \\
{[30]} \\
\text { D. Mabey } \\
{[31]} \\
\text { VR-123 } \\
\text { K. Sachse }\end{array}$ \\
\hline
\end{tabular}

using Plasmid Mini Kit (Qiagen, Crawley, UK). The phage RF DNA was eluted with $50 \mu$ water. A set of custom oligonucleotide primers were designed based on the published Chp2 nucleotide sequence. PCR amplification was performed in a Tetrad Peltier thermal cycler (MJ Research, Watertown, MA) and consisted of 30 cycles of $94^{\circ} \mathrm{C}$ for $15 \mathrm{~s}, 50^{\circ} \mathrm{C}$ for $15 \mathrm{~s}$, and $72^{\circ} \mathrm{C}$ for $40 \mathrm{~s}$, using Bio-X-act polymerase (Bioline, London, $\mathrm{UK}$ ) in a reaction volume of $50 \mu \mathrm{l}$ containing $25 \mathrm{mM}$ TAPS [Tris(hydroxymethyl)-methylamino-propanesulfonic acid sodium salt, pH9.3 (at $\left.\left.25^{\circ} \mathrm{C}\right)\right], 50 \mathrm{mM} \mathrm{KCl}, 2 \mathrm{mM} \mathrm{MgCl}_{2}, 1 \mathrm{mM} \beta$ mercaptoethanol, $200 \mu \mathrm{M}$ each dATP, dGTP, dTTP, and dCTP. Nineteen PCR amplicons (300$800 \mathrm{bp}$ ) covering the entire genome of Chp3 were generated. After purification these PCR fragments were sequenced directly in an Applied Biosystems model 377 automated sequencer using Taq cycle dyedeoxy $^{\mathrm{TM}}$ terminator chemistry. Sequence data computer analyses were performed using the Lasergene software (DNASTAR Inc., Madison, WI). Oligonucleotides were synthesised by Cruachem Ltd (Glasgow, UK). 


\section{Preparation and Purification of Chp3}

BGMK cells were grown as monolayers in $25 \mathrm{~cm}^{2}$ flasks and were infected by centrifugation at $1,000 \times g$ for $1 \mathrm{~h}$ in medium containing cycloheximide $(1 \mu \mathrm{g} / \mathrm{ml})$ and gentamicin $(25 \mu \mathrm{g} / \mathrm{ml})$ with C. pecorum $\mathrm{T} 52$ bearing Chp3. At $72 \mathrm{~h}$ post infection the culture medium was replaced with a small volume of PBS and the flasks frozen at $-70^{\circ} \mathrm{C}$. One hundred flasks of chlamydiaphageinfected chlamydiae were prepared, stored frozen, then processed as a single batch. Flasks were frozen and thawed three times to lyse the chlamydial RBs and release chlamydiaphages. Any remaining monolayer that had not detached after this procedure was scraped off. The suspension was centrifuged at $2,000 \times g$ for 15 min to sediment cell debris. The supernatant was passed through a $0.45 \mu \mathrm{m}$ filter followed by a $0.22 \mu \mathrm{m}$ filter. The filtrate was centrifuged at $100,000 \times g$ in a Beckman SW28 rotor for $3 \mathrm{~h}$ and the resultant pellet washed with PBS and centrifuged at $80,000 \times g$ for $40 \mathrm{~min}$. The pellet was finally suspended in PBS, vortexed with glass beads and stored at $-70^{\circ} \mathrm{C}$ as a partially purified bacteriophage preparation.

\section{Electron Microscopy}

BGMK cells were infected with $C$. pecorum T52 in a six well tray. 48-72 h post infection monolayers were washed in PBS, fixed in 3\% glutaraldehyde in $0.1 \%$ cacodylate buffer and processed for negatively stained thin-section grids [3]. A partially purified preparation of bacteriophage Chp3 was adsorbed onto a formvar coated carbon grid for $2 \mathrm{~min}$, then negatively stained with $0.75 \%$ phospho-tungstic acid pH 6.0 for $10 \mathrm{~s}$ and air dried. EM grids were examined using an Hitachi H7000 transmission electron microscope.

\section{Phylogeny}

Unrooted phylogenetic trees were constructed for the coat protein (VP1) from 5 chlamydiaphages and major coat protein equivalent from a further 7 microviruses. Multiple alignments were performed using CLUSTAL X [33] and unrooted trees were generated using the Neighbour Joining method [34]. Trees were subjected to a bootstrap analysis [35] using 1,000 data sets and, output as a graph- ical representation using DRAWTREE in the PHYLIP package [36].

The complete nucleotide sequence of the Chp3 genome is deposited in GenBank/EMBL accession number AJ550635.

\section{Results and Discussion}

\section{Discovery of Chp3}

The obligate intracellular developmental cycle of the chlamydiae means that it is not possible to undertake conventional approaches for bacteriophage screening and isolation such as plaque assays on agar plates. Searching for new bacteriophages is technically challenging but two approaches are possible; DNA analysis (PCR or hybridisation studies) for the chlamydiaphage genome or screening of chlamydial isolates for bacteriophage antigens. The chlamydial genome sequencing projects have shown that fragments of chlamydiaphage genomes are integrated into the host chromosome [4]. Genome integration is unusual for Microviridae as these bacteriophages do not have a host chromosomal integration step as part of their replicative cycle. In addition to the chlamydial hosts infected with ØCPAR39, phage sequences have been found integrated into the chromosome of chlamydiae that carry no bacteriophages [4]. The possibility exists that chlamydiaphages have integrated random DNA fragments into a variety of chlamydial genomes and then these chlamydiaphage infections have subsequently been naturally "cured". This precludes the use of cross-hybridisation or PCR as a simple means for screening for new chlamydiaphages. Recently, we produced a monoclonal antibody that reacts by immunofluorescence with the coat protein of several chlamydiaphages [5]. Thus our experimental design was to screen a large collection of viable chlamydiae by immunofluorescence staining of chlamydial inclusions with this monoclonal antibody. We screened 39 strains of chlamydiae representing all nine species and found only one positive sample. The positively reacting isolate was a $C$. pecorum from sheep. The identity of the chlamydial isolate was confirmed by PCR with primers U23F and 23SIGR and the sequence of the $23 \mathrm{~S}$ fragment in BLAST searches was 
(A)

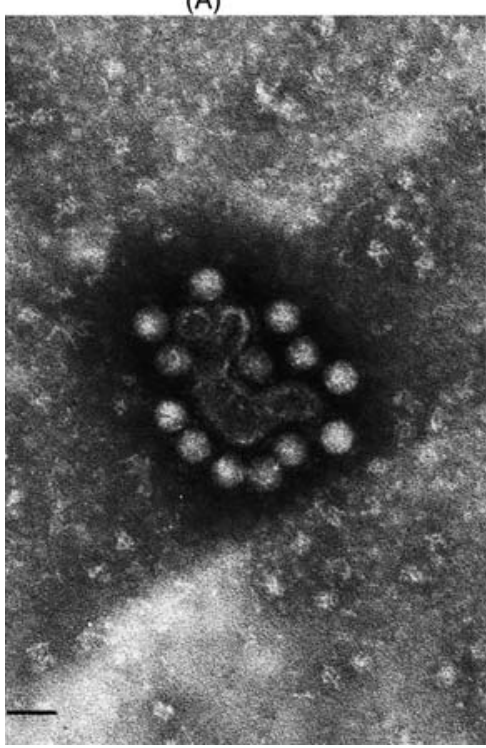

(B)

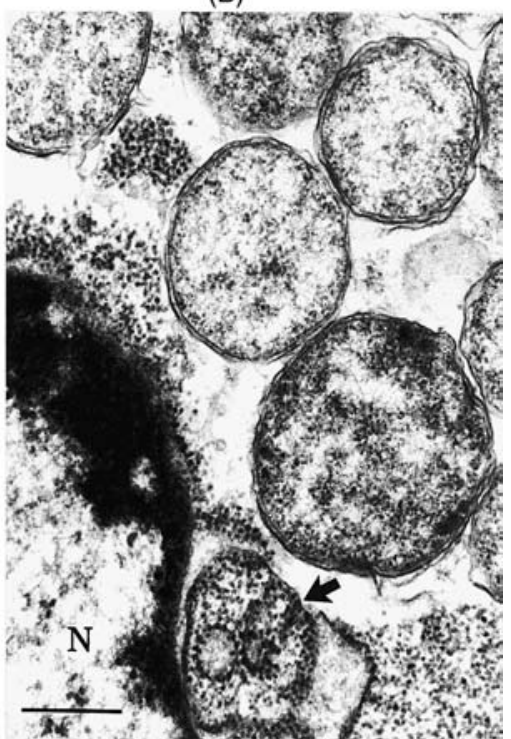

Fig. 1. Electron micrographs of Chp3. (A) Negatively stained cluster of partially purified Chp3 particles. The scale bar represents 50 nm. (B) Thin section transmission electron micrograph of a C. pecorum T52 inclusion at mid developmental cycle showing reticulate bodies in close proximity to the cell nucleus (N). A single RB (arrowed) is infected by Chp3 and has lysed releasing Chp3 particles into the inclusion. The scale bar represents $0.5 \mu \mathrm{m}$.

identical to $C$. pecorum strains I, Z, L71 1 and 1710S [37].

The presence of chlamydiaphage particles in this sample was confirmed by negative stain EM (Fig. 1A) and thin section EM of C. pecorum infected cells (Fig. 1B) that revealed clusters of small round featureless bacteriophage particles within inclusions.

\section{Genome Sequence of Chp3}

The double-stranded DNA replicative form (RF) of Chp3 was extracted from purified $C$. pecorum T52 EBs. The yield of RF DNA was very low, therefore to verify the presence of bacteriophage DNA in the sample, diagnostic PCR primers were designed based on a conserved sequence from the VP1 region of all the chlamydiaphages: ChpDetectF (5'-ATGAAGTTCTYCCTGGAGATAC3') and primer ChpDetectR (5'-GCAACTTTAGTAGGTAGACCAA-3') which amplify a 300 bp fragment of the chlamydiaphage genome. PCR amplification consisted of 30 cycles of $20 \mathrm{~s}$ at $94^{\circ} \mathrm{C}, 20 \mathrm{~s}$ at $44^{\circ} \mathrm{C}$ and $15 \mathrm{~s}$ at $72^{\circ} \mathrm{C}$ using primer pair Chpdetect F and R. A 300 bp fragment was generated and nucleotide sequence analysis con- firmed the sequence of this fragment was unique but related to the Chp2-like bacteriophages (Chp2, ØCPG1 and ØCPAR39).

The DNA sequence of the newly discovered chlamydiaphage genome (hereafter called Chp3) was amplified as a series of 19 overlapping 300800 bp PCR fragments (data not shown). The complete genome sequence of Chp3 is 4,554 bp in length with a nucleotide composition of A (28.7\%); C (18.4\%); G (22.6\%), and T (30.3\%). The overall $\mathrm{G}+\mathrm{C}$ content of Chp3 (41\%) is similar to the other chlamydiaphages $(37-40 \%)$ [38] and also host chlamydial genomes (41\%) [4]. The coding capacity of the Chp3 genome is $97 \%$ it encodes eight ORFs, greater than 99 nucleotides that contain an upstream RBS (VP1, VP2, VP3 and ORFs 4-8): these are also present in the other chlamydiaphages and located in the same genomic context (Fig. 2).

Comparison of the genomes of Chp2, ØCPG1 and ØCPAR39 with Chp3 were performed by the Hein method [39] which is used for performing multiple alignments of related sequences. These chlamydiaphages share; $97.1 \%, 93.4 \%$ and $93.3 \%$ nucleotide sequence identity respectively with Chp3. By contrast, Chp1 is highly divergent with 


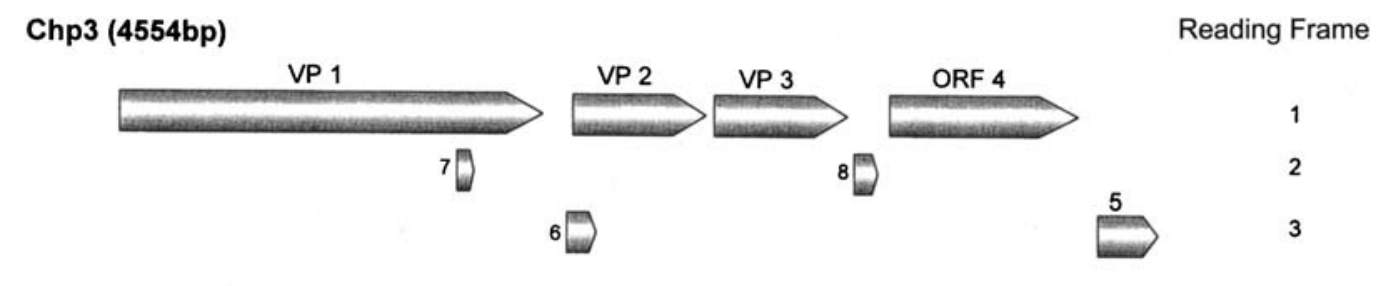

ФCPAR39 (4532bp)
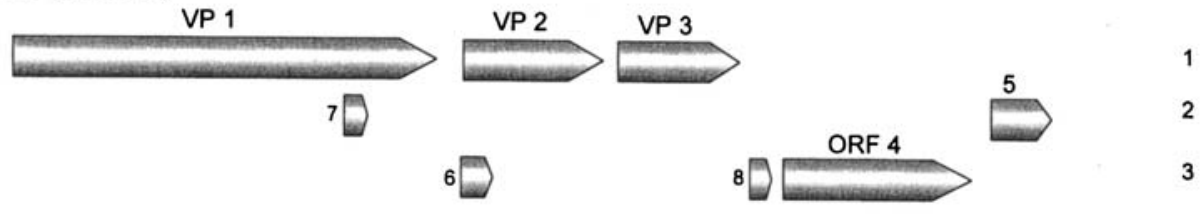

3

ФMH2k (4594bp)
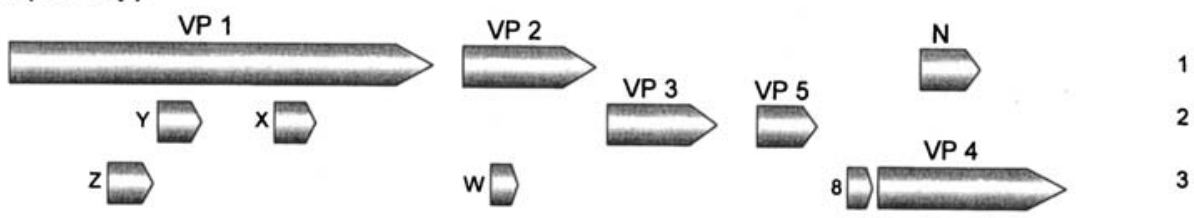

Fig. 2. Comparison and diagrammatic representation of computer-predicted reading frames and genome organisation of Chp3, ØCPAR39 and ØMH2K.

only $51.8 \%$ nucleotide sequence identity. The genome of Chp3 is $9 \mathrm{nt}$ shorter than that of Chp2 because of an $11 \mathrm{nt}$ deletion situated in a noncoding region of the genome $3 \mathrm{nt}$ downstream of the VP3 stop codon. This deletion causes a reading frame shift of ORF8 from frame 1 to 2 relative to Chp2, however a $2 \mathrm{nt}$ insertion downstream of ORF8 restores the reading frame usage to that of Chp2. Similarly the reading frame of ORF8 is different between ØCPAR39 and ØCPG1 moving from frame 1 to 3 . Fig. 2 shows comparison of the genomes of Chp3, ØСРAR39 and ØМН2K from Bdellovibrio bacteriovorus.

\section{Virion Proteins}

Alignment of the structural proteins (VP1, VP2 and VP3) of Chp3 with Chp2, ØCPG1 and ØCPAR39 revealed that both VP2 and VP3 are highly conserved (Table 2). VP2 is thought to be the equivalent of the pilot protein $\mathrm{H}$ from $\varnothing \mathrm{X} 174$ [3]. VP2 from Chp3 share 98.4-98.9\% amino acid sequence identity with VP2 from Chp2, ØCPG1 and ØCPAR39 suggesting the function of this struc- tural protein is highly conserved. Similarly, the Chp3 VP3 (predicted to be the internal scaffolding protein equivalent [3]) shares 96.6-98.0\% amino acid sequence identity with the Chp2-like phages. The protein encoded by ORF8 is quite similar to the ØX174 J protein [3]: the Chp3 ORF8 encoded protein is totally conserved amongst $\mathrm{Chp} 2$, ØCPG1 and ØCPAR39. Some of the Chp3 proteins also closely resemble the equivalent proteins in SpV4 and MH2K. Only weak amino acid sequence identities (\%) are seen between the Chp3 proteins and the proteins of ØX174-like phages.

The chlamydiaphage coat protein, VP1 is the largest of the phage-encoded proteins. Alignments of the amino acid sequences of VP1 revealed two areas of significant divergence between amino acids 216 and 299 and 462 and 467 [38]. It has been hypothesised that the larger of these two regions, known as the IN5 loop, is surface exposed and forms mushroom-like protrusions on the virion surface [40]. While similarities between IN5 sequences and host range support this hypothesis in the Microviridae, the function of the threefold protrusions have never been directly tested. The 
Table 2. Comparison of amino acid sequences for Chp3 ORFs with the other chlamydiaphages, SpV4, ØMH2Kand ØX174

\begin{tabular}{lllllllll}
\hline \multicolumn{7}{l}{$\%$ Amino acid Identity } \\
\cline { 2 - 8 } ORF & $\begin{array}{l}\text { No. of } \\
\text { amino acids }\end{array}$ & Chp1 & Chp2 & ØCPAR39 & ØCPG1 & SpV4 & ØMH2K & ØX174 \\
\hline 1 (VP1) & 565 & 52.5 & 98.1 & 85.2 & 84.8 & $37.0(1)$ & 49.8 & $24.2(\mathrm{~F})$ \\
2 (VP2) & 186 & 39.8 & 98.4 & 98.4 & 98.9 & $36.4(4)$ & 26.0 & $18.2(\mathrm{H})$ \\
3 (VP3) & 148 & 30.9 & 98.0 & 98.0 & 96.6 & $18.7(3)$ & 30.4 & $20.0(\mathrm{~B})$ \\
4 & 315 & 30.3 & 95.3 & 93.4 & 93.2 & $34.4(2)$ & 34.3 & $30.0(\mathrm{~A})$ \\
5 & 84 & 32.9 & 100 & 98.8 & 97.6 & $17.3(5)$ & 39.8 & $17.3(\mathrm{C})$ \\
8 & 44 & 67.6 & 100 & 100 & 100 & $35.9(8)$ & 39.5 & $28.2(\mathrm{~J})$ \\
\hline
\end{tabular}

second smaller region, Ins, is also considered to be surface-exposed and has been predicted to be situated in close proximity and may interact with the IN5 loop [38]. Interestingly the IN5 loop of ØCPG1 and ØCPAR39 [38] and Chp2 and Chp3 are very similar.

An unrooted phylogenetic tree was constructed for the major capsid protein (VP1 equivalent) of 12 members of the Microviridae family of bacterio- phages (Fig. 3). This analysis agrees with the suggestion, based on biological properties [10], that the Microviridae family of bacteriophages can be divided into two types (the ICTV is presently discussing whether these should be genera or subfamilies); the bacteriophages that infect Enterobacteriaceae (including ØX174 and G4) and the bacteriophages that infect obligate intracellular bacteria, which include the chlamydiaphages and

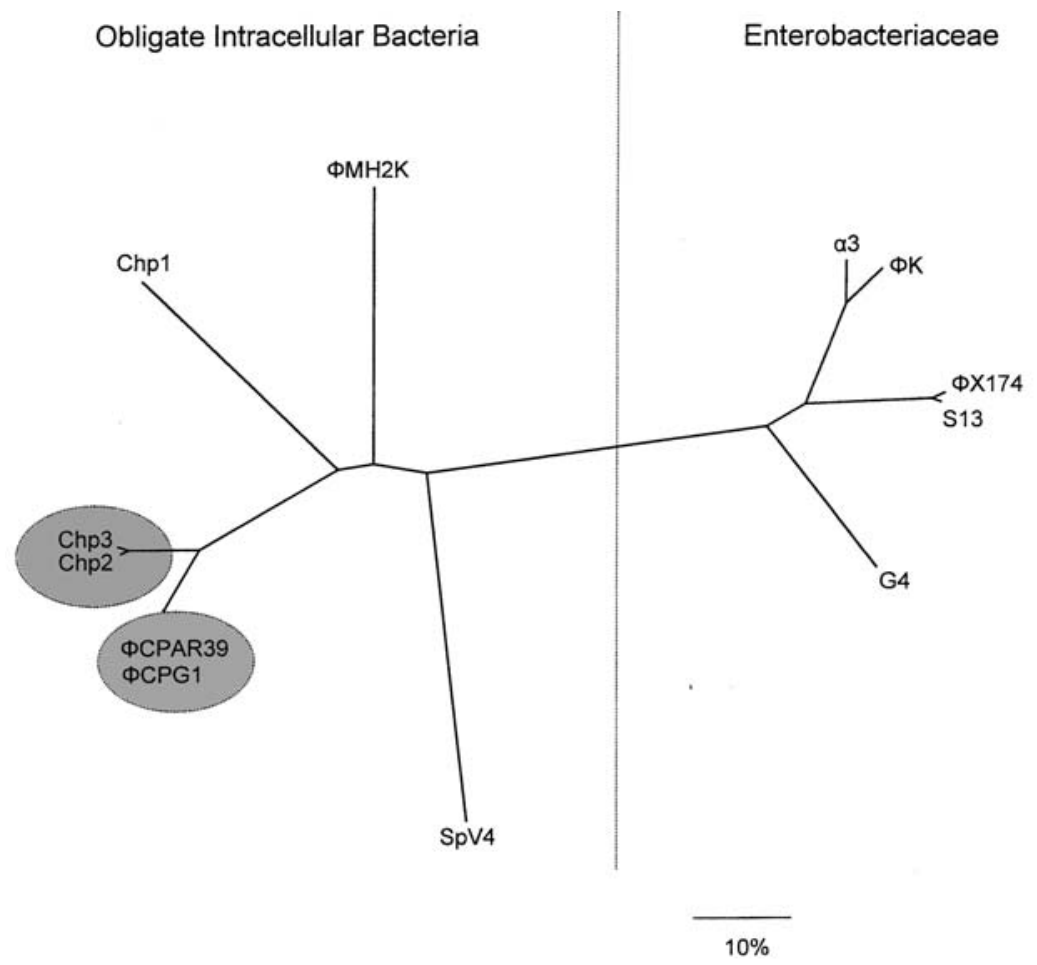

Fig. 3. Unrooted phylogenetic tree constructed for the coat protein (VP1 equivalent) showing the relationship of Chp3 to other microviruses. Shaded ellipses have been added to highlight the distinction between the two available groups of chlamydiaphages. The scale bar indicates percentage divergence. Accession numbers for the microviruses are as follows; X60322 (Ø3), X60323 (ØK), J02482 (ØX174), M14428 (S13), V00657 (G4), AF306496 (ØMH2K), M17988 (SpV4), AJ550635 (Chp3), AJ270057 (Chp2), AE002163 (ØCPAR39), U41758 (ØCPG1), D00624 (Chp1). 
ØМH2K. The name Gokushoviruses (Gokusho: Japanese for very small) has been proposed by the ICTV. The main difference between these two subfamilies of Microviridae is that the "Gokushoviruses" encode neither major spike nor external scaffolding proteins.

\section{Acknowledgements}

This work was supported by grant no. 063882 from the Wellcome Trust. SAG was supported by an MRC research studentship. We are grateful to P. Griffiths, G. Jones, D. Mabey, K. Sachse and J. Treharne for the kind gift of chlamydiae.

\section{References}

1. Richmond S., Stirling P., and Ashley C., in Fifth International Symposium on Human Chlamydial Infections, 1982, pp. 41-44.

2. Hsia R-C., Ohayon H., Gounton P., and Bavoil P.M., in Proceedings of the Third European Society for Chlamydia Research, 1996, p. 48.

3. Liu B.L., Everson J.S., Fane B., Giannikopoulou P., Vretou E., Lambden P.R., and Clarke I.N., J Virol 74, 3464 3469, 2000.

4. Read T.D., Brunham R.C., Shen C., Gill S.R., Heidelberg J.F., White O., Hickey E.K., Peterson J., Utterback T., Berry K., Bass S., Linher K., Weidman J., Khouri H., Craven B., Bowman C., Dodson R., Gwinn M., Nelson W., DeBoy R., Kolonay J., McClarty G., Salzberg S.L., Eisen J., and Fraser C.M., Nucleic Acids Res 28, 1397-1406, 2000.

5. Everson J.S., Garner S.A., Fane B., Liu B.-L., Lambden P.R., and Clarke I.N., J Bacteriol 184, 2748-2754, 2002.

6. Storey C.C., Lusher M., and Richmond S.J., J Gen Virol 70, 3381-3390, 1989.

7. Hsia R.C., Ting L.M., and Bavoil P.M., Microbiology 146, 1651-1660, 2000.

8. Sanger F., Coulson A.R., Friedmann C.T., Air G.M., Barrell B.C., Brown N.L., Fiddes J.C., Hutchison C.A., Slocombe P.M., and Smith M., J Mol Biol 125, 225-246, 1978.

9. Ricard B., Garnier M., and Bové J.M., Rev Infect Dis 4, S275, 2003.

10. Brentlinger K.L., Hafenstein S., Novak C.R., Fane B.A., Borgon R., McKenna R., and Agbandje-McKenna M., J Bacteriol 184, 1089-1094, 2002.

11. Read T.D., Myers G.S., Brunham R.C., Nelson W.C., Paulsen I.T., Heidelberg J., Holtzapple E., Khouri H., Federova N.B., Carty H.A., Umayam L.A., Haft D.H., Peterson J., Beanan M.J., White O., Salzberg S.L., Hsia R-C., McClarty G., Rank R.G., Bavoil P.M., and Fraser C.M., Nucleic Acids Res 31, 2134-2147, 2003.

12. Kalman S., Mitchell W., Marathe R., Lammel C., Fan J., Hyman R.W., Olinger L., Grimwood J., Davis R.W., and Stephens R.S., Nat Genet 21, 385-389, 1999.
13. Shirai M., Hirakawa H., Kimoto M., Tabuchi M., Kishi F., Ouchi K., Shiba T., Ishii K., Hattori M., Kuhara S., and Nakazawa T., Nucleic Acids Res 28, 2311-2314, 2000 .

14. Stephens R.S., Kalman S., Lammel C., Fan J., Marathe R., Aravind L., Mitchell W., Olinger L., Tatusov R.L., Zhao Q., Koonin E.V., and Davis R.W., Science 282, 754 759, 1998.

15. Stephens R.S., Infect Agents and Dis 1, 279-293, 1993.

16. Stamp J.T., McEwen A.D., Watt J.A.A., and Nisbet D.I., The Vet Rec 62, 251-256, 1950.

17. McClenaghan M., Herring A.J., and Aitken I.D., Infect and Immun 45, 384-389, 1984.

18. Griffiths P.C., Philips H.L., Dawson M., and Clarkson M.J., Vet Microbiol 30, 167-177, 1992.

19. Griffiths P.C., Plater J.M., Martin T.C., Hughes S.L., Hughes K.J., Hewinson R.G., and Dawson M., Br Vet J 151, 683-693, 1995.

20. Francis T.J. and Magill T.P., J Exp Med 68, 147-163, 1938.

21. Cello R.M., Am J Opthalmol 63, 1270-1273, 1967.

22. Storz J., Cornell Vet 53, 469-480, 1963.

23. Carter M.W.A., Almahdawi S.A.H., Giles I.G., Treharne J.D., Ward M.E., and Clarke I.N., J Gen Microbiol 137, 465-475, 1991.

24. Wills J.M., Watson G., Lusher M., Mair T.S., Wood D., and Richmond S.J., Vet Microbiol 24, 11-19, 1990.

25. Schachter J., and Meyer K.F., J Bacteriol 99, 636-638, 1969.

26. Jones R.B., and Van der Pol B., in Proceedings of the Seventh International Symposium on Human Chlamydial Infections, 1990, pp. 519-522.

27. Wang S.P, and Grayston J.T., J Immunol 90, 849-856, 1963.

28. Alexander E.R., Wang S.P, and Grayston J.T., Am J Opthalmol 63, 1469-1478, 1967.

29. Johansson M., Schon K., Ward M., and Lycke N., Infect and Immun 65, 1032-1044, 1997.

30. Tuffrey M., Folder P., Gale J., and Taylor-Robinson D., Br J Exp Pathol 67, 605-616, 1986.

31. Hayes L.J., Pickett M.A., Conlan J.W., Ferris S., Everson J.S., Ward M.E., and Clarke I.N., J Gen Microbiol 136, 1559-1566, 1990.

32. Everett K.D.E., Hornung L.J., and Andersen A.A., J Clin Microbiol 37, 575-580, 1999.

33. Thompson J.D., Higgins D.G, and Gibson T.J., 1994. Nucleic Acids Res 22, 4673-4680, 1994.

34. Saitou N., and Nei M., Mol Biol Evol 4, 406-425, 1987.

35. Felsenstein J., Evolution 39, 783-791, 1985.

36. Felsenstein J PHYLIP (Phylogeny Inference Package), version 3.5c. Distributed by author. 1993.

37. Everett K.D., and Andersen A.A., Int J Syst Bacteriol 47, 461-473, 1997.

38. Read T.D., Fraser C.M., Hsia R.C., and Bavoil P.M., Microb Comp Genomics 5, 223-231, 2000.

39. Hein J.J., Meth Enzymol 183, 626-645, 1990.

40. Chipman P.R., Agbandje-McKenna M., Renaudin J., Baker T.S., and McKenna R., Structure 6, 135-145, 1998. 